Research article

\title{
Association between PPARGCIA polymorphisms and the occurrence of nonalcoholic fatty liver disease (NAFLD)
} Masato Yoneda ${ }^{\dagger 1}$, Kikuko Hotta ${ }^{\dagger 2}$, Yuichi Nozaki1 ${ }^{1}$ Hiroki Endo1, Takashi Uchiyama1 ${ }^{1}$ Hironori Mawatari ${ }^{1}$, Hiroshi Iida ${ }^{1}$, Shingo Kato ${ }^{1}$, Kunihiro Hosono ${ }^{1}$, Koji Fujita1, Kyoko Yoneda1', Hirokazu Takahashi Hiroyuki Kirikoshi ${ }^{1}$, Noritoshi Kobayashi ${ }^{1}$, Masahiko Inamori ${ }^{1}$, Yasunobu Abe ${ }^{1}$, Kensuke Kubota1, Satoru Saito1, Shiro Maeyama ${ }^{3}$, Koichiro Wada ${ }^{4}$ and Atsushi Nakajima*1

Address: ${ }^{1}$ Division of Gastroenterology, Yokohama City University Graduate School of Medicine, 3-9 Fuku-ura, Yokohama, Japan, ${ }^{2}$ Laboratory for Endocrinology and Metabolism, Center for Genomic Medicine, RIKEN, 1-7-22 Suehiro, Tsurumi-ku, Yokohama, Japan, ${ }^{3}$ Kitakashiwa Rehabilitation Hospital, 265 Kashiwasita, Kashiwa, Japan and ${ }^{4}$ Department of Pharmacology, Osaka University, Graduate School of Dentistry, 18 Yamadaoka, Suita, Osaka, Japan

Email: Masato Yoneda - yoneda@med.yokohama-cu.ac.jp; Kikuko Hotta - kikuko@src.riken.go.jp; Yuichi Nozaki - fwix0777@nifty.com; Hiroki Endo - t066011b@yokohama-cu.ac.jp; Takashi Uchiyama - maruru0203@yahoo.co.jp; Hironori Mawatari - mawatari-tky@umin.ac.jp; Hiroshi Iida - iida-ham@umin.ac.jp; Shingo Kato - shin800m@yokohama-cu.ac.jp; Kunihiro Hosono - hiro1017@ fukuhp.yokohama-cu.ac.jp; Koji Fujita - t046043e@yokohama-cu.ac.jp; Kyoko Yoneda - t066044@yokohama-cu.ac.jp; Hirokazu Takahashi - hirokazu@med.yokohamacu.ac.jp; Hiroyuki Kirikoshi - hkirikos@med.yokohama-cu.ac.jp; Noritoshi Kobayashi - norikoba@yokohama-cu.ac.jp;

Masahiko Inamori - inamorim@med.yokohama-cu.ac.jp; Yasunobu Abe - a0121@yokohama-cu.ac.jp; Kensuke Kubota - kubotak@yokohamacu.ac.jp; Satoru Saito - ssai1423@yokohama-cu.ac.jp; Shiro Maeyama - shiromaeyama915@msg.biglobe.ne.jp;

Koichiro Wada - kwada@dent.osaka-u.ac.jp; Atsushi Nakajima* - nakajima-tky@umin.ac.jp

* Corresponding author †Equal contributors

Published: 27 June 2008

BMC Gastroenterology 2008, 8:27 doi:10.1 186/147/-230X-8-27
Received: 30 December 2007

Accepted: 27 June 2008

This article is available from: http://www.biomedcentral.com/I47I-230X/8/27

(c) 2008 Yoneda et al; licensee BioMed Central Ltd.

This is an Open Access article distributed under the terms of the Creative Commons Attribution License (http://creativecommons.org/licenses/by/2.0), which permits unrestricted use, distribution, and reproduction in any medium, provided the original work is properly cited.

\begin{abstract}
Background: Genetic factors as well as environmental factors are important in the development of NAFLD and in this study we investigated associations between polymorphisms of peroxisome proliferators-activated receptor $\gamma$ coactivator I $\alpha$ polymorphism (PPARGCIA) and NAFLD.
\end{abstract}

Aims: We recruited II 5 patients with biopsy-proven NAFLD, 65 with NASH and 50 with simple steatosis, and 44I healthy control subjects and investigated I5 SNPs of PPARGCIA.

Results: SNP rs2290602 had the lowest $p$ value in the dominant mode $(p=0.00095)$, and the odds ratio for NAFLD (95\% CI) was 2.73 (I.48 - 5.06). rs2290602 was significantly associated with NAFLD even when the most conservative Bonferroni's correction was applied $(p=0.0143)$. The frequency of the T allele of rs2290602 was significantly higher in the NASH patients than in the control subjects $(p=0.00093$, allele frequency mode), and its frequency in the NASH patients tended to be higher than in the simple steatosis patients $(p=0.09)$. The results of the real-time RT-PCR study showed that intrahepatic mRNA expression of PPARGCIA was lower in the TT group than in the GG or GT group at SNP rs2290602 $(p=0.0454)$.

Conclusion: This is the first study to demonstrate a significant association between genetic variations in PPARGCIA and NAFLD. This finding suggested that PPARGCIA polymorphism and lower expression of PPARGCIA mRNA in the liver are an important genetic contribution to etiology of NAFLD. 


\section{Background}

Nonalcoholic fatty liver disease (NAFLD) is one of the most common causes of chronic liver injury in many countries in the world $[1,2]$, and epidemiological studies have shown that its prevalence ranges from $17 \%$ to $33 \%$ of the general population. NAFLD represents a spectrum of conditions that are histologically characterized by macrovesicular hepatic steatosis, and the diagnosis is made in patients who have not consumed alcohol in amounts sufficient to be considered to be harmful to the liver. The histological changes range over a wide spectrum, extending from simple steatosis, which is generally non-progressive, to nonalcoholic steatohepatitis (NASH), liver cirrhosis, liver failure, and sometimes even hepatocellular carcinoma $[3,4]$.

Genetic factors as well as environmental factors are important to the development of NAFLD [5-8], and the gene for peroxisome proliferator-activated receptor $\gamma$ coactivator $1 \alpha(P P A R G C 1 A)$ is a candidate gene for susceptibility to NAFLD, since it is involved in insulin resistance, mitochondrial biogenesis, and oxidative phosphorylation, which are key factors in the development of NAFLD [9-11]. Recent evidence also implicates PPARGC1A in the homeostatic control of systemic energy metabolism, and PPARGC1A knockout mice have been reported to develop hepatic steatosis due to a combination of reduced mitochondrial respiratory capacity and increased expression of lipogenic genes [12]. Single nucleotide polymorphisms (SNPs) are useful tools in the search for genetic factors responsible for disease and are being intensively investigated in various common diseases, such as obesity, diabetes, and hypertension. Expression of PPARGC1A has been reported to be associated with metabolic factors, such as type 2 diabetes, hypertension, obesity [13-18].

In this study we investigated associations between SNPs of PPARGC1A and NAFLD in the Japanese subjects.

\section{Methods}

\section{Subjects}

A total of 115 Japanese NAFLD patients, 65 with NASH and 50 with simple steatosis, and 441 healthy control subjects were recruited to participate in this study at Yokohama City University Hospital. All control subjects were confirmed to have normal liver function, not to have viral hepatitis, and not to be alcoholics. The control subjects all had a BMI $<25 \mathrm{~kg} / \mathrm{m}^{2}$, normal fasting glucose $(<110 \mathrm{mg} /$ $\mathrm{dl})$, serum triglycerides $(<150 \mathrm{mg} / \mathrm{dl})$, and serum HDL cholesterol $(>40 \mathrm{mg} / \mathrm{dl})$ levels, and normal systolic $(<130$ $\mathrm{mmHg}$ ) and diastolic blood pressure $(<85 \mathrm{mmHg})$. Liver biopsy was performed in all 115 NAFLD patients, and the liver biopsy tissue obtained was stained with hematoxylin-eosin, reticulin stain, and Masson trichrome stain. The histological criterion used to make the diagnosis of
NAFLD was the presence of macrovesicular fatty change in hepatocytes with displacement of the nucleus to the edge of the cell [19]. When more than 5\% of hepatocytes were affected by macrovesicular steatosis, the patient was diagnosed as having either steatosis or steatohepatitis. The criteria used to make the diagnosis of steatohepatitis were the presence of lobular inflammation and the presence of either ballooning cells or perisinusoidal/pericellular fibrosis in zone 3 of the hepatic acinus, in addition to steatosis $[20,21]$. Patients with any of the following diseases were excluded from participation in this study: infectious hepatitis (chronic hepatitis $\mathrm{C}$ infection or concurrent active hepatitis $\mathrm{B}$ virus), autoimmune hepatitis, primary biliary cirrhosis (PBC), sclerosing cholangitis, hemochromatosis, $\alpha 1$-antitrypsin deficiency, Wilson's disease, druginduced hepatitis, and alcoholic hepatitis, and heavy alcohol consumers (current or past daily consumption of more than $20 \mathrm{~g}$ alcohol per day). No patients had clinical evidence of hepatic decompensation, such as hepatic encephalopathy, ascites, variceal bleeding, or a serum billirubin level greater than twice the upper limit of normal.

Written informed consent was obtained from all subjects before their entry into this study. The study protocol conformed to the ethical guidelines of the 1975 Declaration of Helsinki and was approved by the Research Committee of Yokohama City Hospital.

\section{Physical and laboratory evaluation}

The body weight and height of the patients were measured with a calibrated scale after requesting them to remove their shoes and any heavy clothing. A venous blood sample was obtained from the patients after an overnight fast (12 hours) to measure their serum AST, ALT, glucose, immunoreactive insulin (IRI), hemoglobin A1c (HbA1c), total cholesterol, HDL cholesterol, and triglyceride levels. All laboratory biochemical parameters were measured with a conventional automated analyzer. Visceral fat area (VFA) and subcutaneous fat area (SFA) were measured by computed tomography (CT).

\section{DNA preparation and SNP genotyping}

Genomic DNA was prepared from each blood sample by using a commercial genomic DNA extraction kit (TALENT s.r.l., Trieste, Italy). The PPARGC1A SNPs were selected from the IMS-JST (Institute of Medical Science-Japan Science and Technology Agency) SNP database [22]. We selected the 15 SNPs with a minor allele frequency greater than 0.2 and whose expected allele frequencies did not widely diverge from Hardy-Weinberg equilibrium $(p>$ 0.001 ). Invader probes (Third Wave Technologies, Madison, WI) were synthesized for these SNPs, and the SNPs were genotyped in the cases and controls by a combination of multiplex PCR and the Invader assay, as described previously [23]. 


\section{Real-time RT-PCR for measurement of PPARGCAI mRNA expression}

Total RNA was isolated from samples of liver biopsy specimens by using an RNeasy Mini Kit (Quiagen, Hilden, Germany) according to the manufacturer's instructions. The protocol included a DNase treatment step to remove genomic DNA. The RNA was assessed quantitatively by measuring relative absorbance at $260 \mathrm{~nm}$ and $280 \mathrm{~nm}$, and qualitatively by ethidium bromide agarose-gel electrophoresis. Reverse transcription to produce cDNA was performed by using a TaqMan Reverse Transcription Reagents (Applied Biosystems, Foster City, CA, USA), according to the manufacturer's instructions. The reaction mixtures $(100 \mu \mathrm{l})$ contained $2.5 \mu \mathrm{g}$ of total RNA, and after allowing the reaction to proceed for 50 minutes at $48^{\circ} \mathrm{C}$, the reverse transcriptase was inactivated by heating the samples to $95^{\circ} \mathrm{C}$ for 5 minutes.

Real-time quantitative RT-PCR was performed in triplicate by using an ABI Prism 7700 sequence detection system (Applied Biosystems, Foster City, CA, USA) and SYBR Green PCR Master Mix according to the manufacturer's protocol. The following primers were used: PPARGC1A $(\mathrm{F}$, 5'-TCTGACGTGACCATGGTGTT-3'; R, 5'-CATTCCAGGGACTCCACACT-3'). The primers were designed with Primer Express software (Applied Biosystems, Foster City, CA, USA) based on the sequence data obtained from the GenBank database. $\beta$-actin (Applied Biosystems, Foster City, CA, USA) was used as a reference; i.e., each sample was normalized on the basis of its $\beta$-actin content. Thermal cycling was performed as follows: initial denaturation at $95^{\circ} \mathrm{C}$ for 10 minutes, followed by 40 cycles of $95^{\circ} \mathrm{C}$ for 15 seconds and $60^{\circ} \mathrm{C}$ for 1 minute.

\section{Statistical analysis}

For each case-control study, the frequencies of the genotypes or the alleles were compared between cases and controls in three different modes by means of the $\chi^{2}$ test. In the first mode (allele frequency mode), allele frequencies were compared between cases and controls by means of a $2 \times 2$ contingency table. In the second mode (recessive mode), the frequencies of the subjects who were homozygous for allele 1 were compared with the rest by means of a $2 \times 2$ contingency table, while in the third mode (dominant mode) the frequencies of the subjects who had allele 1 (allele 1 homozygotes and heterozygotes) were compared with the rest by means of a $2 \times 2$ contingency table. The odds ratio (OR) and its 95\% confidence interval (CI) were calculated by Woolf's method. Conformity to the Hardy-Weinberg equilibrium was assessed by the $\chi^{2}$ test [24]. Haplotype blocks were calculated using Haploview 3.2 software [25]. Physical and laboratory data are reported as means \pm standard deviation (SD).

\section{Results}

\section{Case-control association study}

The characteristics of NAFLD groups and control group are compared in Table 1 . We selected the 15 SNPs of the PPARG1A gene in the IMS-JST SNP database that had a minor allele frequency greater than 0.2 . The information on SNP location has been added in Table 2 and Fig. 1. The rs2290602 SNP had the lowest $p$ value in the dominant mode ( $p=0.00095$, Table 2), and rs2290602 was significantly associated with NAFLD even when the most conservative Bonferroni's correction was applied ( $p=0.00095$ $\times 15 \times 3=0.04275)$. The OR $(95 \% \mathrm{CI})$ was $2.73(1.48-$ $5.06)$ in the dominant mode, and thus the relative risk of developing NAFLD of the subjects with the T allele was 2.73 fold higher than among the subjects without the $\mathrm{T}$ allele. All SNPs except rs2290602 were in Hardy-Weinberg equilibrium $(p>0.1)$. The departure of rs2290602 from the Hardy-Weinberg equilibrium was detected in the NAFLD group ( $p=0.02)$, because this SNP is associated with NAFLD and the cases were selected for the phenotype. Case may be biased compared to the general popu-

Table I: Characteristics of the NAFLD patients and control subjects.

\begin{tabular}{|c|c|c|c|}
\hline & Control & NAFLD & $P$-value \\
\hline Men/Women & $112 / 329$ & $51 / 64$ & \\
\hline Age (years) & $47.4 \pm 15.9$ & $49.6 \pm 15.1$ & 0.20 \\
\hline $\mathrm{BMI}\left(\mathrm{kg} / \mathrm{m}^{2}\right)$ & $21.2 \pm 2.2$ & $27.4 \pm 5.3$ & $<0.0001$ \\
\hline FBS (mg/dL) & $90.4 \pm 7.4$ & $117.2 \pm 32.0$ & $<0.0001$ \\
\hline $\mathrm{HbAlc}(\%)$ & $5.1 \pm 0.6$ & $5.8 \pm 1.3$ & $<0.0001$ \\
\hline Total Cholesterol (mg/dL) & $200.9 \pm 33.4$ & $211.7 \pm 36.5$ & 0.0027 \\
\hline Triglycerides (mg/dL) & $72.2 \pm 27.6$ & $168.9 \pm 110.7$ & $<0.0001$ \\
\hline HDL cholesterol (mg/dL) & $68.1 \pm 13.9$ & $52.9 \pm 20.9$ & $<0.0001$ \\
\hline Systolic blood pressure (mmHg) & $110.5 \pm 9.9$ & $124.1 \pm 14.8$ & $<0.0001$ \\
\hline Diastolic blood pressure $(\mathrm{mmHg})$ & $69.2 \pm 7.3$ & $76.8 \pm 11.3$ & $<0.0001$ \\
\hline AST (IU/L) & $20.1 \pm 6.3$ & $44.4 \pm 26.3$ & $<0.0001$ \\
\hline ALT (IU/L) & $15.7 \pm 6.5$ & $70.4 \pm 53.6$ & $<0.0001$ \\
\hline
\end{tabular}

Data are means \pm SD. 
Table 2: Genotype frequencies and association tests of SNPs PPARGCIA gene using NAFLD and control

\begin{tabular}{|c|c|c|c|c|c|c|c|c|c|c|c|c|c|c|c|c|c|}
\hline \multirow[t]{2}{*}{ Rs number } & \multirow[t]{2}{*}{ Location } & \multirow{2}{*}{$\begin{array}{l}\text { allelel/ } \\
\text { allele2 }\end{array}$} & \multicolumn{3}{|c|}{ NAFLD } & \multicolumn{3}{|c|}{ Control } & \multicolumn{3}{|c|}{ Allele frequency mode } & \multicolumn{3}{|c|}{ Recessive mode } & \multicolumn{3}{|c|}{ Dominant mode } \\
\hline & & & 11 & 12 & 22 & 11 & 12 & 22 & $\chi^{2}$ & $P$-value & $\mathrm{OR}^{\mathrm{a}}(95 \% \mathrm{Cl})$ & $\chi^{2}$ & $P$-value & $\mathrm{OR}^{\mathrm{a}}(95 \% \mathrm{Cl})$ & $\chi^{2}$ & $P$-value & $\mathrm{OR}^{\mathrm{a}}(95 \% \mathrm{Cl})$ \\
\hline rs3774902 & Intron I +745 & $\mathrm{T} / \mathrm{C}$ & 46 & 49 & 19 & 207 & 170 & 63 & 1.6 & 0.2008 & $\begin{array}{c}0.82 \\
(0.61-1.11)\end{array}$ & 1.6 & 0.2010 & $\begin{array}{c}0.76 \\
(0.50-1.16)\end{array}$ & 0.4 & 0.52917 & $\begin{array}{c}0.84 \\
(0.48-1.46)\end{array}$ \\
\hline rs297087I & Intron I +945 & $\mathrm{A} / \mathrm{G}$ & 31 & 64 & 19 & 121 & 212 & 107 & 1.0 & 0.3225 & $\begin{array}{c}1.16 \\
(0.87-1.55)\end{array}$ & 0.0 & 0.9478 & $\begin{array}{c}0.98 \\
(0.62-1.56)\end{array}$ & 3.0 & 0.08241 & $\begin{array}{c}1.61 \\
(0.94-2.75)\end{array}$ \\
\hline rs2970876 & Intron I +2908 & $\mathrm{C} / \mathrm{T}$ & 38 & 55 & 22 & 109 & 226 & 102 & 2.8 & 0.0964 & $\begin{array}{c}1.28 \\
(0.96-1.72)\end{array}$ & 3.1 & 0.0804 & $\begin{array}{c}1.49 \\
(0.95-2.32)\end{array}$ & 0.9 & 0.33573 & $\begin{array}{c}1.29 \\
(0.77-2.15)\end{array}$ \\
\hline rs2290604 & Intron $4+848$ & $\mathrm{~A} / \mathrm{G}$ & 77 & 33 & 3 & 261 & 159 & 21 & 3.2 & 0.0716 & $\begin{array}{c}1.42 \\
(0.97-2.07)\end{array}$ & 3.0 & 0.0815 & $\begin{array}{c}1.48 \\
(0.95-2.29)\end{array}$ & 1.0 & 0.32629 & $\begin{array}{c}1.83 \\
(0.54-6.26)\end{array}$ \\
\hline rs3774907 & Intron $5+|6|$ & $\mathrm{T} / \mathrm{C}$ & 75 & 35 & 3 & 280 & 138 & 21 & 0.6 & 0.4292 & $\begin{array}{c}1.16 \\
(0.80-1.69)\end{array}$ & 0.3 & 0.6083 & $\begin{array}{c}1.12 \\
(0.72-1.73)\end{array}$ & 1.0 & 0.32239 & $\begin{array}{c}1.84 \\
(0.54-6.29)\end{array}$ \\
\hline rs3774908 & Intron $5+1089$ & $\mathrm{~T} / \mathrm{C}$ & 79 & 33 & 3 & 261 & 158 & 21 & 3.6 & 0.0580 & $\begin{array}{c}1.44 \\
(0.99-2.10)\end{array}$ & 3.4 & 0.0661 & $\begin{array}{c}\mid .5 \mathrm{I} \\
(0.97-2.33)\end{array}$ & 1.0 & 0.30970 & $\begin{array}{c}1.87 \\
(0.55-6.39)\end{array}$ \\
\hline rs2290603 & Intron $5+3590$ & $\mathrm{~A} / \mathrm{G}$ & 75 & 35 & 4 & 264 & 154 & 19 & 1.0 & 0.3075 & $\begin{array}{c}I .2 \mid \\
(0.84-1.75)\end{array}$ & 1.1 & 0.2933 & $\begin{array}{c}1.26 \\
(0.82-1.94)\end{array}$ & 0.2 & 0.68996 & $\begin{array}{c}1.25 \\
(0.42-3.75)\end{array}$ \\
\hline rs2290602 & Intron $7+|7|$ & $\mathrm{T} / \mathrm{G}$ & 34 & 67 & 13 & 99 & 222 & 113 & 8.5 & 0.0036 & $\begin{array}{c}1.55 \\
(1.15-2.08)\end{array}$ & 2.4 & 0.1201 & $\begin{array}{c}1.44 \\
(0.91-2.28)\end{array}$ & 10.9 & 0.00095 & $\begin{array}{c}2.73 \\
(1.48-5.06)\end{array}$ \\
\hline rs2970849 & Intron $7+8096$ & $\mathrm{~A} / \mathrm{G}$ & 68 & 42 & 5 & 232 & 173 & 34 & 2.2 & 0.1385 & $\begin{array}{c}1.30 \\
(0.92-1.82)\end{array}$ & 1.4 & 0.2287 & $\begin{array}{c}1.29 \\
(0.85-1.96)\end{array}$ & 1.6 & 0.20492 & $\begin{array}{c}1.85 \\
(0.7 \mid-4.83)\end{array}$ \\
\hline rs2932968 & Intron $7+8494$ & $\mathrm{~T} / \mathrm{C}$ & 74 & 36 & 4 & 262 & 157 & 21 & 1.2 & 0.2809 & $\begin{array}{c}1.22 \\
(0.85-1.76)\end{array}$ & 1.1 & 0.2959 & $\begin{array}{c}1.26 \\
(0.82-1.93)\end{array}$ & 0.3 & 0.56233 & $\begin{array}{c}1.38 \\
(0.46-4.10)\end{array}$ \\
\hline rs3755863 & $\begin{array}{c}\text { Exon } 8+707 \\
(T / T)\end{array}$ & $\mathrm{G} / \mathrm{A}$ & 32 & 60 & 23 & 82 & 222 & 135 & 7.3 & 0.0070 & $\begin{array}{c}1.49 \\
(1.11-2.00)\end{array}$ & 4.7 & 0.0308 & $\begin{array}{c}1.68 \\
(1.05-2.69)\end{array}$ & 5.2 & 0.02301 & $\begin{array}{c}1.78 \\
(1.08-2.93)\end{array}$ \\
\hline rs 3736265 & $\begin{array}{c}\text { Exon } 9+42 \\
(M / T)\end{array}$ & $\mathrm{A} / \mathrm{G}$ & 81 & 30 & 3 & 261 & 158 & 20 & 5.0 & 0.0259 & $\begin{array}{c}1.55 \\
(1.05-2.29)\end{array}$ & 5.2 & 0.0231 & $\begin{array}{c}1.67 \\
(1.07-2.62)\end{array}$ & 0.8 & 0.35922 & $\begin{array}{c}1.77 \\
(0.52-6.05)\end{array}$ \\
\hline rs3774920 & Intron $10+1732$ & $\mathrm{~A} / \mathrm{G}$ & 79 & 32 & 3 & 263 & 157 & 21 & 3.8 & 0.0528 & $\begin{array}{c}1.46 \\
(0.99-2.14)\end{array}$ & 3.6 & 0.0587 & $\begin{array}{c}1.53 \\
(0.98-2.37)\end{array}$ & 1.0 & 0.31886 & $\begin{array}{c}1.85 \\
(0.54-6.31)\end{array}$ \\
\hline rs768695 & Intron $12+4535$ & $\mathrm{~T} / \mathrm{C}$ & 69 & 35 & 9 & 229 & 184 & 27 & 1.2 & 0.2737 & $\begin{array}{c}1.21( \\
0.86-1.70)\end{array}$ & 2.9 & 0.0863 & $\begin{array}{c}1.44 \\
(0.95-2.20)\end{array}$ & 0.5 & 0.48225 & $\begin{array}{c}0.76 \\
(0.34-1.66)\end{array}$ \\
\hline rs3774923 & Exon $13+2485$ & $A / G$ & 82 & 30 & 3 & 263 & 157 & 20 & 5.0 & 0.0256 & $\begin{array}{c}1.55 \\
(1.05-2.29)\end{array}$ & 5.2 & 0.0232 & $\begin{array}{c}1.67 \\
(1.07-2.61)\end{array}$ & 0.9 & 0.35349 & $\begin{array}{c}1.78 \\
(0.52-6.09)\end{array}$ \\
\hline
\end{tabular}

a OR; odds ratio,

lation. Thus, it is not unexpected that case was not in Hardy-Weinberg equilibrium. Linkage disequilibrium (LD) analysis revealed the presence of two blocks in the PPARG1A gene. SNP rs2290602 and 11 other SNPs (rs2290604, rs3774907, rs3774908, rs2290603, rs2970849, rs2932968, rs3755863, rs3736265, rs3774920, rs768695, and rs3774923) were in the same block (Fig. 1).

Next, we divided the NAFLD group into the NASH and the steatosis group and used rs2290602 to perform case-control association studies. Although it was not conclusive because of the small number of data, the frequency of $\mathrm{T}$ allele was significantly higher in the NASH group than in the control group ( $\mathrm{p}=0.00093$, allele frequency mode). When the frequency of the T allele in the NASH group was compared to its frequency in the steatosis group, its frequency was found to tend to be higher than in the steatosis group ( $p=0.09)$. Thus, rs2290602 was significantly more closely associated with NASH than with simple steatosis (Table 3).

To investigate whether the genotype of rs2290602 SNP were associated with the clinical parameters, we compared age, $\mathrm{BMI}$, and the fasting plasma glucose, immunoreacrive insulin, HbA1c, total cholesterol, triglyceride, HDL cho- lesterol, AST, ALT, VFA, and SFA between the NAFLD patients with different genotypes (GG vs. GT + TT, or TT vs. GT + GG) by Student's $t$-test. The results showed that serum AST and ALT values of the NAFLD patients with the TT allele were significantly higher than those of the NAFLD patients with the GT or GG allele at SNP rs2290602 (Table 4). When the subjects were limited to the NASH patients, the serum AST and ALT values were also significantly higher in the TT genotype group than in the GT group or GG group at SNP rs2290602 ( $p=0.0177$, $p=0.0140$, respectively).

\section{mRNA expression of PPARGCIA in the liver}

Expression of PPARGC1A mRNA in the liver biopsy specimens of NAFLD patients was evaluated by real-time RTPCR. The results obtained by real-time RT-PCR in the GG or GT group $(\mathrm{n}=10)$ were compared with the results in the TT group $(\mathrm{n}=8)$ at SNP rs2290602. As shown in Fig. 2, the expression of PPARGC1A mRNA transcripts in the liver was significantly lower in the TT group than in the GG or GT group ( $\mathrm{p}=0.0454)$.

\section{Discussion}

Genetic factors are important to the development of NAFLD, and recent advantages in SNP genotyping methods have enabled the detection of genetic the variations 


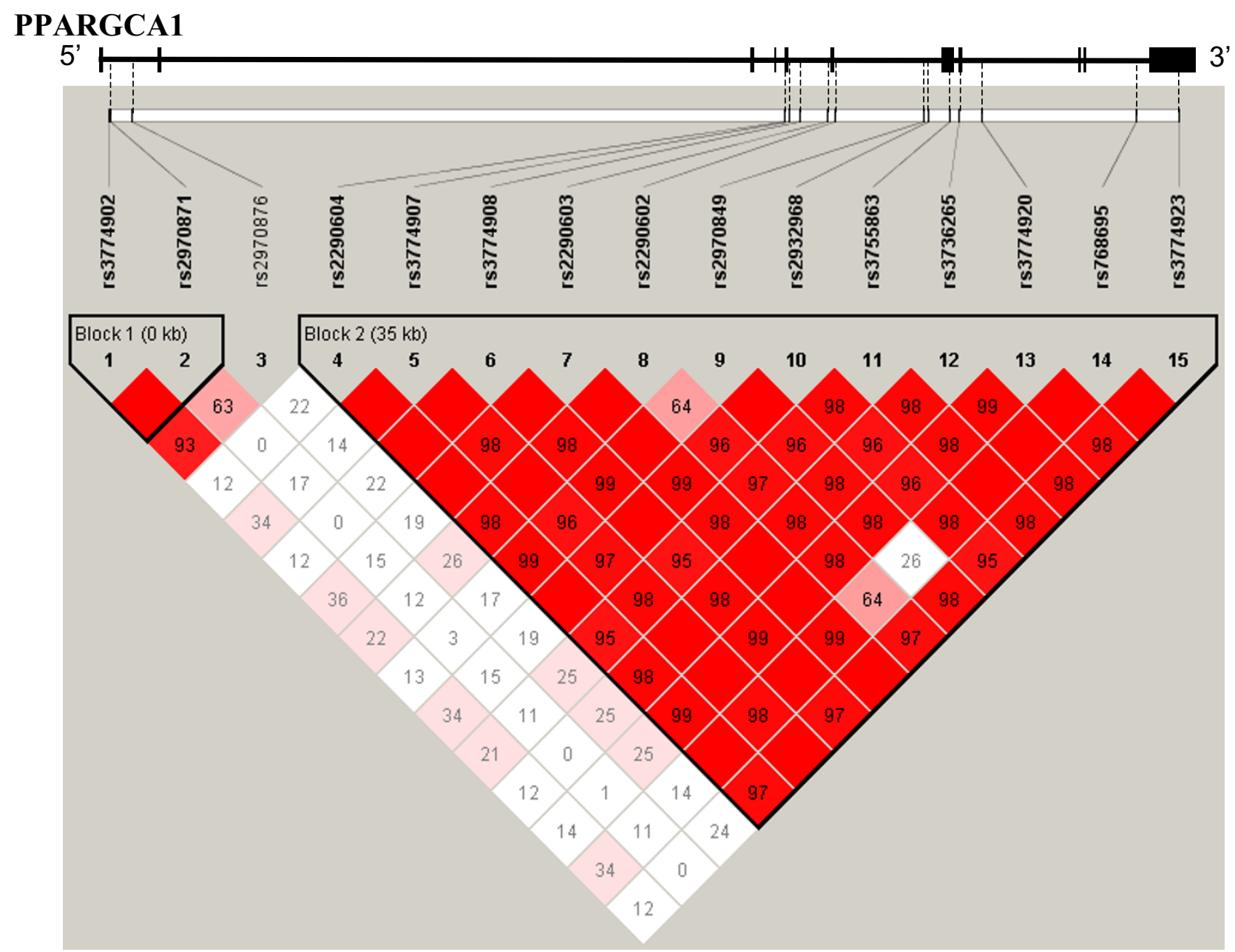

\section{Figure I}

LD mapping around the PPARGCIA gene. LD coefficients (d) were calculated for every pair of PPARGCIA SNPs. LD coefficients $\left(\mathrm{D}^{\prime}\right)$ were calculated for every pair of SNPs and are shown as the strand of the LD blocks. The minor allele frequencies of all SNPs used in this analysis were $>20 \%$. Each SNP is labeled with its rs number.

associated with increased susceptibility to NAFLD. There have been a few reports of genetic variations that are associated with NAFLD, and they have been in the genes for
TNF receptor 2 (TNFR-2), TNF- $\alpha$, micorosomal triglyceride transfer protein (MTP), and methylenetetrahydrofolate reductase (MTHFR) genes $[6,7,26]$. All of these

Table 3: Results of testing for differences in SNP rs2290602 frequency between NAFLD group and control group, NASH group and contol group, NASH group and simple steatosis group.

\begin{tabular}{|c|c|c|c|c|c|c|c|c|c|c|c|c|c|c|c|}
\hline \multirow[b]{2}{*}{ Study } & \multicolumn{3}{|c|}{ NAFLD } & \multicolumn{3}{|c|}{ Control } & \multicolumn{3}{|c|}{ Allele frequency mode } & \multicolumn{3}{|c|}{ Recessive mode } & \multicolumn{3}{|c|}{ Dominant mode } \\
\hline & 11 & 12 & 22 & 11 & 12 & 22 & $\chi^{2}$ & $P$-value & $\begin{array}{l}\text { Odds ratio } \\
(95 \% \mathrm{Cl})\end{array}$ & $\chi^{2}$ & $P$-value & $\begin{array}{l}\text { Odds ratio } \\
(95 \% \mathrm{Cl})\end{array}$ & $\chi^{2}$ & $P$-value & $\begin{array}{l}\text { Odds ratio } \\
(95 \% \mathrm{Cl})\end{array}$ \\
\hline $\begin{array}{l}\text { NAFLD vs. } \\
\text { Control }\end{array}$ & 34 & 67 & 13 & 99 & 222 & 113 & 1.6 & 0.00363 & $\begin{array}{c}1.55 \\
(1.15-2.08)\end{array}$ & 2.4 & 0.12008 & $\begin{array}{c}1.44 \\
(0.91-2.28)\end{array}$ & 10.9 & 0.00095 & $\begin{array}{c}2.73 \\
(1.48-5.06)\end{array}$ \\
\hline NASH vs. Control & 24 & 34 & 6 & 99 & 222 & 113 & 1.0 & 0.00093 & $\begin{array}{c}1.90 \\
(1.29-2.79)\end{array}$ & 6.5 & 0.01097 & $\begin{array}{c}2.03 \\
(1.17-3.53)\end{array}$ & 8.5 & 0.00352 & $\begin{array}{c}3.40 \\
(1.43-8.10)\end{array}$ \\
\hline $\begin{array}{l}\text { NASH vs. simple } \\
\text { steatosis }\end{array}$ & 24 & 34 & 6 & 10 & 33 & 7 & 2.8 & 0.09168 & $\begin{array}{c}1.58 \\
(0.93-2.69)\end{array}$ & 4.1 & 0.04270 & $\begin{array}{c}2.40 \\
(1.02-5.66)\end{array}$ & 0.6 & 0.44076 & $\begin{array}{c}1.57 \\
(0.49-5.02)\end{array}$ \\
\hline
\end{tabular}


Table 4: Comparison between various quantitative phenotypes in groups of NAFLD patients with different SNP genotypes at rs2290602

\begin{tabular}{|c|c|c|c|c|c|c|}
\hline & GG & $\mathrm{GT}+\mathrm{TT}$ & $P$ value & $\mathrm{GG}+\mathrm{GT}$ & TT & $P$ value \\
\hline $\mathrm{N}$ & 14 & 101 & & 80 & 35 & \\
\hline Age (years) & $48.5+18.5$ & $49.5+14.7$ & 0.8303 & $48.4+14.4$ & $51.7+16.4$ & 0.2913 \\
\hline BMI (kg/m2) & $27.3+7.2$ & $27.2+4.8$ & 0.9194 & $27.0+5.1$ & $27.6+4.9$ & 0.5581 \\
\hline FBS (mg/dl) & $118.5+26.3$ & $117.3+32.9$ & 0.8929 & $116.8+32.0$ & $118.7+32.8$ & 0.7791 \\
\hline IRI (ul/ml) & $13.6+6.2$ & $13.7+8.9$ & 0.9778 & $12.9+6.9$ & $15.4+11.6$ & 0.1865 \\
\hline HbAlc (\%) & $5.39+1.26$ & $5.88+1.26$ & 0.1890 & $5.83+1.28$ & $5.80+1.23$ & 0.9138 \\
\hline Total cholesterol $(\mathrm{mg} / \mathrm{dl})$ & $219.1+35.7$ & $213.1+39.3$ & 0.6017 & $214.7+39.5$ & $211.6+37.5$ & 0.6978 \\
\hline HDL cholesterol (mg/dl) & $50.6+10.0$ & $53.3+22.0$ & 0.6709 & $51.2+16.2$ & $57.0+29.1$ & 0.1800 \\
\hline Triglycerides (mg/dl) & $144.9+53.7$ & $172.1+116.4$ & 0.4102 & 159.1 + 70.4 & $192.2+172.3$ & 0.1469 \\
\hline AST (U/ml) & $35.0+12.2$ & $45.8+27.5$ & 0.1660 & $40.4+21.3$ & $54.5+34.1$ & 0.0085 \\
\hline ALT (U/ml) & $50.4+27.2$ & $73.4+55.7$ & 0.1462 & $62.7+37.7$ & $89.9+76.9$ & 0.0127 \\
\hline VFA (cm2) & $129.3+32.9$ & $135.8+50.0$ & 0.7585 & $135.4+47.4$ & $134.9+51.3$ & 0.9703 \\
\hline SFA (cm2) & $274.6+148.9$ & $229.4+116.8$ & 0.3821 & $235.4+123.8$ & $230.4+114.2$ & 0.8709 \\
\hline
\end{tabular}

Data are shown as means \pm SD. VFA: visceral fat area, SFA: subcutaneous fat area, AST: aspartate aminotransferase, ALT: alanine aminotransferase, FBS: fasting blood sugar, IRI: Immunoreactive insulin,

genes are related to inflammation, lipid metabolism, and oxidation. We examined the 15 SNPs in PPARGC1A and found that rs2290602 was significantly associated with NAFLD, especially with NASH, and the frequency of the T allele of rs2290602 was significantly higher in the NASH patients than in the control subjects. We also found that intrahepatic PPARGC1A mRNA expression was significantly lower in the TT group than in the GG or GT group at SNP rs2290602.

PPARGC1A interacts with peroxisome proliferators-activated receptors (PPARs) and has various functions, including as integrator of the molecular regulatory cir-

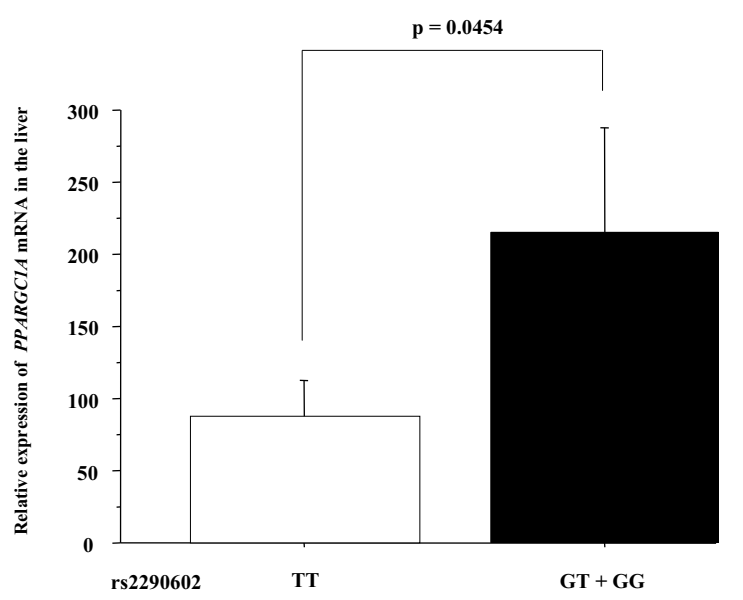

Figure 2

The expression of $m R$ NA for PPARGCIA in the liver. Significant difference in intrahepatic $m R N A$ expression of PPARGCIA between the TT group $(n=8)$ and the GG or GT group $(n=10)$ at SNP rs2290602 $(p=0.0454)$. cuitry involved in the transcriptional control of cellular energy metabolism, including mitochondrial function and biogenesis $[27,28]$, and regulation of gene expression involved in lipid and glucose metabolism. The PPARGC1A Gly482Ser polymorphism is also associated with obesity, hypertension, and diabetes [14-18,29]. NAFLD is often accompanied by obesity, hypertriglyceridemia, type 2 diabetes, and insulin resistance [30], and PPARGC1A knockout mice develop hepatic steatosis [12]. Thus, variations in rs2290602 in the PPARGC1A gene would be expected to affect lipid and glucose metabolism, and result in the development of NAFLD and NASH.

Recent evidence also implicates PPARGC1A in the homeostatic control of systemic energy metabolism, and PPARGC1A has been shown to regulate several key hepatic gluconeogenic genes [31-34]. Recent studies have also shown altered expression of PPARGC1A and downstream mitochondrial target pathways in the skeletal muscle of humans with insulin resistance and diabetes [3537].

This study had a limitation in regard to the control subjects. The number of the patients was too small for a polymorphism study. Although none of the control subjects had abnormal liver function or was obese, we cannot completely rule out the possibility that the control group included patients with mild steatosis, since we did not perform liver biopsies in the control subjects.

\section{Conclusion}

In conclusion, this is the first study to demonstrate a significant association between genetic variations in PPARGC1A and NAFLD. This finding suggested that PPARGC1A polymorphism and lower expression of 
PPARGC1A mRNA in the liver are an important genetic contribution to the etiology of NAFLD.

\section{Abbreviations}

BMI: body mass index; NAFLD: nonalcoholic fatty liver disease; NASH: nonalcoholic steatohepatitis; SNPs: single nucleotide polymorphisms; VFA: visceral fat area; SFA: subcutaneous fat area; AST: aspartate aminotransferase; ALT: alanine aminotransferase.

\section{Competing interests}

The authors declare that they have no competing interests.

\section{Authors' contributions}

MY performed the literature review, collected the clinical data, and drafted the manuscript, with contributions from $\mathrm{YN}, \mathrm{HE}$, and $\mathrm{KH}$. KF and $\mathrm{KH}$ organized the field survey for data collection. SK, HM, KY, HT, HK, MI, YA, KK, SS, and WK collected the clinical data. SM analyzed the liver pathology. HI, KH, TU, and NK revised the manuscript. AN was responsible for the design of the study. All authors read and approved the final manuscript.

\section{Acknowledgements}

Special thanks to the staff of the SNP Research Center of RIKEN for their contribution to our study. This work was supported in part by a Grant-inAid for research on the Third Comprehensive Control Research for Cancer from the Ministry of Health, Labor and Welfare of Japan to A.N., a grant from the National Institute of Biomedical Innovation (NBIO) to A.N., a grant from the Ministry of Education, Culture, Sports, Science and Technology of Japan (KIBAN-B) to A.N., and a research grant of the Princess Takamatsu Cancer Research Fund to A.N. This work was supported by a grant from the Japanese Millennium Project (K. H.).

\section{References}

I. Angulo P: Nonalcoholic fatty liver disease. N Engl J Med 2002, 18:|22|-3|.

2. Farrell GC: Non-alcoholic steatohepatitis: what is it, and why is it important in the Asia-Pacific region? J Gastroenterol Hepatol 2003, I 8: 124-38.

3. Diehl AM, Goodman Z, Ishak KG: Alcohol-like liver disease in nonalcoholics. A clinical and histologic comparison with alcohol-induced liver injury. Gastroenterology 1988, 95: 1056-62.

4. Ludwig J, Viggiano TR, McGill DB, Oh BJ: Nonalcoholic steatohepatitis: Mayo Clinic experiences with a hitherto unnamed disease. Mayo Clin Proc 1980, 55:434-8.

5. Nozaki Y, Nemoto Y, Ono M, Akisawa N, Saibara T, Hiroi M, Enzan $\mathrm{H}$, Onishi S: Polymorphisms of microsomal triglyceride transfer protein gene and manganese superoxide dismutase gene in non-alcoholic steatohepatitis.

6. Gambino R, Cassader M, Pagano G, Furazzo M, Musso G: Polymorphism in microsomal triglyceride transfer protein: a link between liver disease and atherogenic postprandial lipid profile in NASH? Hepatology 2007, 45: 1097-107.

7. Tokushige K, Takakura M, Tsuchiya-Matsushita N, Taniai M, Hashimoto E, Shiratori K: Influence of TNF gene polymorphisms in Japanese patients with NASH and simple steatosis. J Hepatol 2007, 46: I 104-10.

8. Merriman RB, Aouizerat BE, Bass NM: Genetic influences in nonalcoholic fatty liver disease. J Clin Gastroenterol 2006, 40:S30-3.

9. Chitturi S, Abeygunasekera S, Farrell GC, Holmes-Walker J, Hui JM, Fung C, Karim R, Lin R, Samarasinghe D, Liddle C, Weltman M, George ]: NASH and insulin resistance: Insulin hypersecretion and specific association with the insulin resistance syndrome. Hepatology 2002, 35:373-9.
10. Sanyal AJ, Campbell-Sargent C, Mirshahi F, Rizzo WB, Contos MJ, Sterling RK, Luketic VA, Shiffman ML, Clore JN: Nonalcoholic steatohepatitis: association of insulin resistance and mitochondrial abnormalities. Gastroenterology 200 I, I 20: I |83-92.

II. Cortez-Pinto H, Chatham J, Chacko VP, Arnold C, Rashid A, Diehl AM: Alterations in liver ATP homeostasis in human nonalcoholic steatohepatitis: a pilot study. JAMA 1999, 282:1659-64.

12. Leone TC, Lehman JJ, Finck BN, Schaeffer PJ, Wende AR, Boudina S, Courtois M, Wozniak DF, Sambandam N, Bernal-Mizrachi C, Chen Z, Holloszy JO, Medeiros DM, Schmidt RE, Saffitz JE, Abel ED, Semenkovich CF, Kelly DP: PGC-I alpha deficiency causes multi-system energy metabolic derangements: muscle dysfunction, abnormal weight control and hepatic steatosis. PLOS Biol 2005, 3:elol.

13. Oberkofler H, Linnemayr V, Weitgasser R, Klein K, Xie M, Iglseder B, Krempler F, Paulweber B, Patsch W: Complex haplotypes of the PGC-I alpha gene are associated with carbohydrate metabolism and type 2 diabetes. Diabetes 2004, 53: 1385-93.

14. Ek J, Andersen G, Urhammer SA, Gaede PH, Drivsholm T, BorchJohnsen $\mathrm{K}$, Hansen T, Pedersen O: Mutation analysis of peroxisome proliferator-activated receptor-gamma coactivator-I (PGC-I) and relationships of identified amino acid polymorphisms to Type II diabetes mellitus. 200I, 44:2220-6.

15. Esterbauer $\mathrm{H}$, Oberkofler $\mathrm{H}$, Linnemayr V, Iglseder B, Hedegger $M$, Wolfsgruber P, Paulweber B, Fastner G, Krempler F, Patsch W: Peroxisome proliferator-activated receptor-gamma coactivator-I gene locus: associations with obesity indices in middleaged women. Diabetes 2002, 5 I: I 28I-6.

16. Hara K, Tobe K, Okada T, Kadowaki H, Akanuma Y, Ito C, Kimura S, Kadowaki T: A genetic variation in the PGC-I gene could confer insulin resistance and susceptibility to Type II diabetes. Diabetologia 2002, 45:740-743.

17. Ridderstrale M, Johansson LE, Rastam L, Lindblad U: Increased risk of obesity associated with the variant allele of the PPARGCIA Gly482Ser polymorphism in physically inactive elderly men. Diabetologia 2006, 49:496-500.

18. Xie G, Guo D, Li Y, Liang S, Wu Y: The impact of severity of hypertension on association of PGC-I a Gene with blood pressure and risk of hypertension. BMC Cardiovasular Disorders 2007, 7:33.

19. Sanyal AJ: AGA technical review on nonalcoholic fatty liver disease. Gastroenterol 2002, I 23:1705-25

20. Matteoni CA, Younossi ZM, Gramlich T, Boparai N, Liu YC, McCullough AJ: Nonalcoholic fatty liver disease: a spectrum of clinical and pathological severity. Gastroenterology 1999, II6:1413-9.

21. Teli MR, James OF, Burt AD, Bennett MK, Day CP: The natural history of nonalcoholic fatty liver: a follow-up study. Hepatology 1995, 22:17|4-9.

22. Hirakawa M, Tanaka T, Hashimoto Y, Kuroda M, Takagi T, Nakamura Y: JSNP: a database of common gene variations in the Japanese population. Nucleic Acids Res 2002, 30: I58-62.

23. Dennis G Jr, Sherman BT, Hosack DA, Yang J, Gao W, Lane HC, Lempicki RA: DAVID: Database for Annotation, Visualization, and Integrated Discovery. Genome Biol 2003, 4:P3

24. Nielsen DM, Ehm MG, Weir BS: Detecting marker-disease association by testing for Hardy-Weinberg disequilibrium at a marker locus. Am J Hum Genet 1998, 63: I53I-40.

25. Barrett JC, Fry B, Maller J, Daly MJ: Haploview: analysis and visualization of LD and haplotype maps. Bioinformatics 2005, 2I:263-5

26. Serin E, Güçlü M, Ataç FB, Verdi H, Kayaselçuk F, Ozer B, Bilezikçi B, Yilmaz U: Methylenetetrahydrofolate reductase $C 677 \mathrm{~T}$ mutation and nonalcoholic fatty liver disease. Dig Dis Sci 2007, 52: II83-6.

27. Kelly DP, Scarpulla RC: Transcriptional regulatory circuits controlling mitochondrial biogenesis and function. Genes Dev 2004, 18:357-368

28. Puigserver P, Wu Z, Park CW, Graves R, Wright M, Spiegelman BM: $A$ cold-inducible coactivator of nuclear receptors linked to adaptive thermogenesis. Cell 1998, 92:829-839.

29. Ambye L, Rasmussen S, Fenger M, Jørgensen T, Borch-Johnsen $K$, Madsbad S, Urhammer SA: Studies of the Gly482Ser polymorphism of the peroxisome proliferator-activated receptor gamma coactivator Ialpha (PGC-Ialpha) gene in Danish subjects with the metabolic syndrome. Diabetes Res Clin Pract $2005,67: 175-9$ 
30. Younossi ZM, Diehl AM, Ong JP: Nonalcoholic fatty liver disease: an agenda for clinical research. Hepatology 2002, 35:746-752.

31. Herzig S, Long F, Jhala US, Hedrick S, Quinn R, Bauer A, Rudolph D, Schutz G, Yoon C, Puigserver P, Spiegelman B, Montminy M: CREB regulates hepatic gluconeogenesis through the coactivator PGC-I. 200I.

32. Yoon JC, Puigserver P, Chen G, Donovan J, Wu Z, Rhee J, Adelmant G, Stafford J, Kahn CR, Granner DK, Newgard CB, Spiegelman BM: Control of hepatic gluconeogenesis through the transcriptional coactivator PGC-I. Nature 200I, 4I3:13I-8.

33. Puigserver P, Rhee J, Donovan J, Walkey CJ, Yoon JC, Oriente F, Kitamura Y, Altomonte J, Dong H, Accili D, Spiegelman BM: Insulin-regulated hepatic gluconeogenesis through FOXOI-PGCIalpha interaction. Nature 2003, 423:550-5.

34. Herzig S, Lee $\mathrm{CH}$, Hedrick S, Kulkarni R, Evans RM, Olefsky J, Montminy M: PGC-I promotes insulin resistance in liver through PPAR-alpha-dependent induction of TRB-3. 2004.

35. Lindgren CM, Eriksson KF, Subramanian A, Sihag S, Lehar J, Puigserver $P$, Carlsson E, Ridderstråle M, Laurila E, Houstis N, Daly MJ, Patterson N, Mesirov JP, Golub TR, Tamayo P, Spiegelman B, Lander ES, Hirschhorn JN, Altshuler D, Groop LC: PGC-Ialpha-responsive genes involved in oxidative phosphorylation are coordinately downregulated in human diabetes. 2003, 34:267-73.

36. Patti ME, Butte AJ, Crunkhorn S, Cusi K, Berria R, Kashyap S, Miyazaki Y, Kohane I, Costello M, Saccone R, Landaker EJ, Goldfine AB, Mun E, DeFronzo R, Finlayson J, Kahn CR, Mandarino LJ: Coordinated reduction of genes of oxidative metabolism in humans with insulin resistance and diabetes: Potential role of $\mathrm{PGCI}$ and NRFI. 2003, 100:846671.

37. Dufour S, Befroy D, Garcia R, Shulman GI: Impaired mitochondrial activity in the insulin-resistant offspring of patients with type 2 diabetes. N Eng J Med 2004, 350:664-7I.

\section{Pre-publication history}

The pre-publication history for this paper can be accessed here:

http://www.biomedcentral.com/1471-230X/8/27/pre pub

\section{Publish with Biomed Central and every scientist can read your work free of charge}

"BioMed Central will be the most significant development for disseminating the results of biomedical research in our lifetime. "

Sir Paul Nurse, Cancer Research UK

Your research papers will be:

- available free of charge to the entire biomedical community

- peer reviewed and published immediately upon acceptance

- cited in PubMed and archived on PubMed Central

- yours - you keep the copyright 